\title{
Does government ideology influence deregulation of product markets? Empirical evidence from OECD countries
}

\author{
Niklas Potrafke
}

\begin{abstract}
This paper examines how government ideology has influenced deregulation of product markets in OECD countries. I analyze a dataset of non-manufacturing regulation indicators covering energy, transport and communication industries in 21 OECD countries over the 1980-2003 period and employ two different indices of government ideology. The results suggest that government ideology has had a strong influence on the deregulation process: market-oriented governments promoted the deregulation of the energy, transport and communication industries. This finding identifies remarkable differences between leftist and rightwing governments concerning the role of government in the economy and basic elements of political order.
\end{abstract}

Keywords Product market deregulation · Government ideology · Panel data

JEL Classification $\mathrm{D} 72 \cdot \mathrm{L} 50 \cdot \mathrm{P} 16 \cdot \mathrm{C} 23$

\section{Introduction}

The role of government in the economy is a core conflict area between leftist and marketoriented governments: leftist governments favor more government responsibilities than market-oriented governments. These differences are not restricted to fiscal policy but also concern other basic elements of political order.

Scholars have investigated how government ideology influences the privatization process and economic freedom in developed and developing countries. Panel data studies suggest that rightwing and market-oriented governments were the driving force of the privatization process and of expanding economic freedom. The influence of government ideology on product market deregulation, however, has been ignored. Given the importance of ideologyinduced preferences concerning the size and scope of government, this is a notable omission.

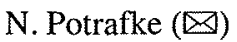

Department of Economics, University of Konstanz, Box 138, 78457 Konstanz, Germany

e-mail: niklas.potrafke@uni-konstanz.de 
In this paper, I employ the dataset compiled by Conway and Nicoletti (2006) in order to examine whether market-oriented governments have been more active in deregulating product markets in the 1980-2003 period. ${ }^{1}$ My study uses two indices of government ideology that explicitly refer to the left-right scale of the governing parties. The results suggest that government ideology has had a strong influence on the deregulation process: marketoriented governments promoted the deregulation of the energy, transport and communication industries. This finding identifies remarkable differences between leftist and rightwing governments concerning the role of government in the economy and basic elements of political order.

The paper is organized as follows: Section 2 discusses theoretical and empirical literature on government ideology and deregulation, privatization and economic freedom and thus formulates the hypothesis to be tested. Section 3 presents the data on product market regulation and specifies the empirical model. Section 4 reports and discusses the estimation results, and investigates their robustness. Section 5 concludes.

\section{Government ideology and deregulation}

\subsection{Schools of thought}

Deregulation is clearly related to market-oriented economics and, therefore, rightwing governments. According to this ideology, the state should intervene as little as possible in the economy confining itself to maintaining the legal framework necessary for a market system. Rightwing parties prefer protection of property rights, rule of law and legal quality more than leftwing parties because they desire to protect merit and the gains from talent (Bjørnskov 2005a, 2005b). State intervention is justified in this context only if it attacks or restricts obstacles to efficient market behavior or counteracts 'market failure'.

The Austrian School of Economics, for example, portrays the dangers of government intervention (see Kurrild-Klitgaard 2005 for an introduction to the Mises-Hayek political economy of government intervention). Advocates of the Chicago School have also opposed government regulation in general, but they view antitrust as a desirable public interest intervention designed to correct market failures implicit in monopoly (Rowley and Rathbone 2004: 187). Friedman (1962: 2) maintains that: “. . the scope of government must be limited. Its major function must be to protect our freedom both from the enemies outside our gates and from our fellow-citizens: to preserve law and order, to enforce private contracts, to foster competitive markets." In particular, Friedman (1962: 35) lists concrete policy activities undertaken by the US government in the 1950s and 1960s that are not in line with market-oriented principles: "Detailed regulation of industries, such as the regulation of transportation by the Interstate Commerce Commission. This had some justification on technical monopoly grounds when initially introduced for railroads; it has none for any means of transport." For a more encompassing portrait of the political economy of economic freedom see, for example, Peacock (1997).

\footnotetext{
${ }^{1}$ Scholars have used these data to investigate the influence of product market policies on different dimensions of economic performance such as fiscal adjustment or employment and wages (see, for example, Tagkalakis 2009 and Berger and Danninger 2007). I am aware only of one study by Heinemann (2007), however, that uses a previous version of this dataset as the dependent variable.

${ }^{2}$ On categories of government and market failure see, for example, Munger (2008).
} 
The schools of economic thought are clearly related to political ideology and parties' beliefs. ${ }^{3}$ Benoit and Laver (2006) measure policy positions of political parties in 47 countries. Employing expert surveys, they portray party positions on different policy issues, among them deregulation. Experts were asked to scale political party attitudes on deregulation in the interval 1 (favors high levels of state regulation and control of the market) and 20 (favors deregulation of markets at every opportunity). The results unmistakably suggest that rightwing parties prefer much more deregulation than leftwing parties.

\subsection{Related empirical studies and the hypothesis to be tested}

Market-oriented and rightwing governments favor a small role and size of government as well as more economic freedom in several policy fields. In fiscal and monetary policy, for example, rightwing governments are expected to employ restrictive policies such as cutting taxes, keeping the budget balanced and preferring tight monetary policies by conservative central bankers. Several studies have examined the influence on government ideology in these policy fields; the results are somewhat mixed (see, for example, Alesina et al. 1997 and Sakamoto 2008). Investigating the influence of government ideology in the area of industrial policy has, however, been widely ignored and appears to be a worthwhile endeavor.

Empirical studies suggest that rightwing and market-oriented governments have advanced privatization and economic freedom. In OECD countries, the privatization process started in the late 1980s (with the notable exceptions of the United Kingdom and the United States, when privatization began a decade earlier). The empirical studies by Bortolotti et al. (2001, 2003) and Bortolotti and Pinotti (2008) clearly show that rightwing governments have forced this privatization process. In Central and Eastern Europe, privatization was also introduced by rightwing and market-oriented governments. In the rapid transition process of the early 1990 s, leftist governments stuck to public ownership much more strongly than in the following period from the mid 1990s to 2007 (Bjørnskov and Potrafke 2009). In Turkey, rightwing governments fostered privatization of cement firms (Arin and Ulubaşoğlu 2009). ${ }^{4}$

Another strand of literature deals with liberalization of wide-ranging economic policies or economic freedom. Pitlik (2007), for example, analyzes the determinants of economic policy reform among OECD countries over the 1970-2000 period. He employs the economic freedom indices of the Fraser Institute and finds a robust negative relation between leftist governments and economic liberalization in general and government regulation in particular. Bjørnskov (2005a) also uses the indices of the Fraser Institute and reports greater economic freedom under rightwing governments in a panel of developed and developing countries.

Scholars hardly have examined the influence of government ideology on deregulation. This is a notable omission given the clear-cut differences between leftist and rightwing ideologies on this policy issue. Two main kinds of deregulation are distinguished in the literature: labor market and product market deregulation.

\footnotetext{
${ }^{3}$ Leftwing parties have not been associated with market-oriented policies at all. Friedman (1962: 21), for example, calls the Socialists and Communists as "the enemies of the free-market".

${ }^{4}$ Imai (2009) investigates the privatization of Japan's postal saving system from a political economy perspective, and also stresses the importance of politicians' fundamental ideologies on the size and scope of government.
} 
Labor market deregulation in the European Union, however, does not appear to be related to government ideology. The frequency of EU labor market directives can neither be explained by the partisan composition of the Council, nor by the national level of labor market regulation (see the case study evidence by Vaubel 2008: 462). ${ }^{5}$ In OECD countries, market-oriented governments deregulated labor markets to some extent. Potrafke (2009a) analyzes whether globalization has influenced labor market deregulation and also controls for government ideology. He employs the dataset by Bassanini and Duval (2006), which tackles various aspects of labor market deregulation, and finds that only deunionization took place under rightwing governments. Duval (2008) investigates whether fiscal and monetary policies have fostered reforms in labor and product markets in OECD countries from 1985-2003. He examines reforms on the unemployment benefit systems, labor taxes, employment protection legislation, product market regulation and retirement schemes and also includes a government ideology variable. Duval (2008) distinguishes between two different empirical approaches. Employing a multivariate probit model, his results suggest that government ideology did not have an influence on the five reform indicators. Employing a linear regression approach and an aggregate reform indicator, his results suggest that market-oriented governments have fostered reforms. It is important to note, however, that (1) neither study focuses explicitly on the influence of government ideology on labor market deregulation, and (2) neither study examines all-embracing indicators but various aspects of labor market deregulation. For this reason, further research on this particular issue is required.

Product market deregulation is likely to be driven by rightwing governments. Two studies explicitly focus on this issue. Duso (2007) analyzes regulatory intervention and entry liberalization in the digital mobile telecommunications industries of OECD countries in the 1991-1997 period. His results suggest that rightwing governments were more favorable to deregulation and liberalization. Kroszner and Strahan (1998) investigate bank branching deregulation across the US states. Their results indicate that a larger share of Democrats in the government tends to delay deregulation. In conclusion, the interaction of government ideology and product market deregulation requires an empirical evaluation. The hypothesis to investigate is the following:

Market-oriented and rightwing governments have been more active in deregulating product markets.

\section{Data and empirical strategy}

\subsection{Data on product market regulation}

I use the dataset on product market regulation compiled by Conway and Nicoletti (2006). This dataset, which is available for the 1975-2003 period, contains yearly data for 21 OECD countries: Australia, Austria, Belgium, Canada, Denmark, Finland, France, Germany, Greece, Ireland, Italy, Japan, the Netherlands, New Zealand, Norway, Portugal, Spain, Sweden, Switzerland, the UK, and the USA (balanced panel).

\footnotetext{
${ }^{5}$ See also Vaubel (2008) for a survey of the political economy of labor market deregulation by the European Union.
} 
Conway and Nicoletti (2006) describe their measures of product market regulation as follows: "the indicators focus on regulations that affect competitive pressures in areas where competition is economically viable and on the potential costs that these regulations entail for economic activities that use the output of regulated sectors as intermediate inputs in production" (p. 3). "All of these indicators are constructed from the perspective of regulations that create barriers to entrepreneurship and restrict competition in domestic markets where technology and demand conditions make competition viable. It is important to note from the onset that the sole objective of the indicators is to quantify the degree to which regulatory settings in a given sector are anti-competitive. They make no attempt to measure the stance of regulation with respect to public policy goals other than promoting competition" (p. 6).

The non-manufacturing indicators of regulation can be divided into three broad categories. The first group of indicators measures regulatory restrictions in energy, transport and communication (henceforth ETCR). The second group of indicators assesses regulation in retail distribution and some business services (RBSR). The third group of indicators, called the regulatory impact indicators, is derived from the first two groups plus an indicator of anti-competitive regulation in the finance sector.

In this paper, I focus on the ETCR indicators for two reasons. First, only for this group of indicators are annual data available. ${ }^{6}$ Second, competition issues are of paramount importance in energy, transport and communication, where public legal monopolies were not uncommon in OECD countries.

The ETCR indicators measure restrictions to competition in the seven most regulated industries in OECD countries (electricity, gas, air passenger transport, rail transport, road freight, postal services and telecommunications). ${ }^{7}$

“...these sectors have long been (and partly still are) characterized by the presence of natural monopoly segments and network externalities, and firms have typically been burdened with non-economic objectives (such as universal service obligations). In many countries, legal restrictions to entry, widespread public ownership, and extensive cross-subsidies have often been seen as the only way to address these problems. These regulatory arrangements have seldom been challenged by international competition, given that these sectors were relatively closed to international trade and investment until recently. However, over time, technological advances, the evolution of governance and regulatory techniques, as well as increasing international exposure have made liberalisation and privatisation increasingly possible in these sectors. The ETCR indicators endeavour to capture these developments" (p. $15 \mathrm{f}$.).

The ETCR indicators include two main low-level indicators: barriers to entry and public ownership. The appendix contains a detailed description of the components applicable to the electricity, transport and communications industries. To keep the empirical analysis manageable, I focus on the four aggregated indicators: "Aggregate ETCR", "All but public ownership", "Entry barriers" and "Public ownership". The indicators take on values between 0 (minimum of regulation) and 6 (maximum of regulation).

\footnotetext{
${ }^{6}$ The indicators for retail distribution and professional services are available for 1998 and 2003 in 30 OECD countries.

${ }^{7}$ The indicators suggest considerable variation in the stringency of regulation across industries. In some industries, such as road freight, air transport, and telecommunications, regulation appears to have been completely overhauled. In other industries, such as gas, postal services, and rail transport, regulatory reforms appear to have been minor (Conway and Nicoletti 2006: 18).
} 


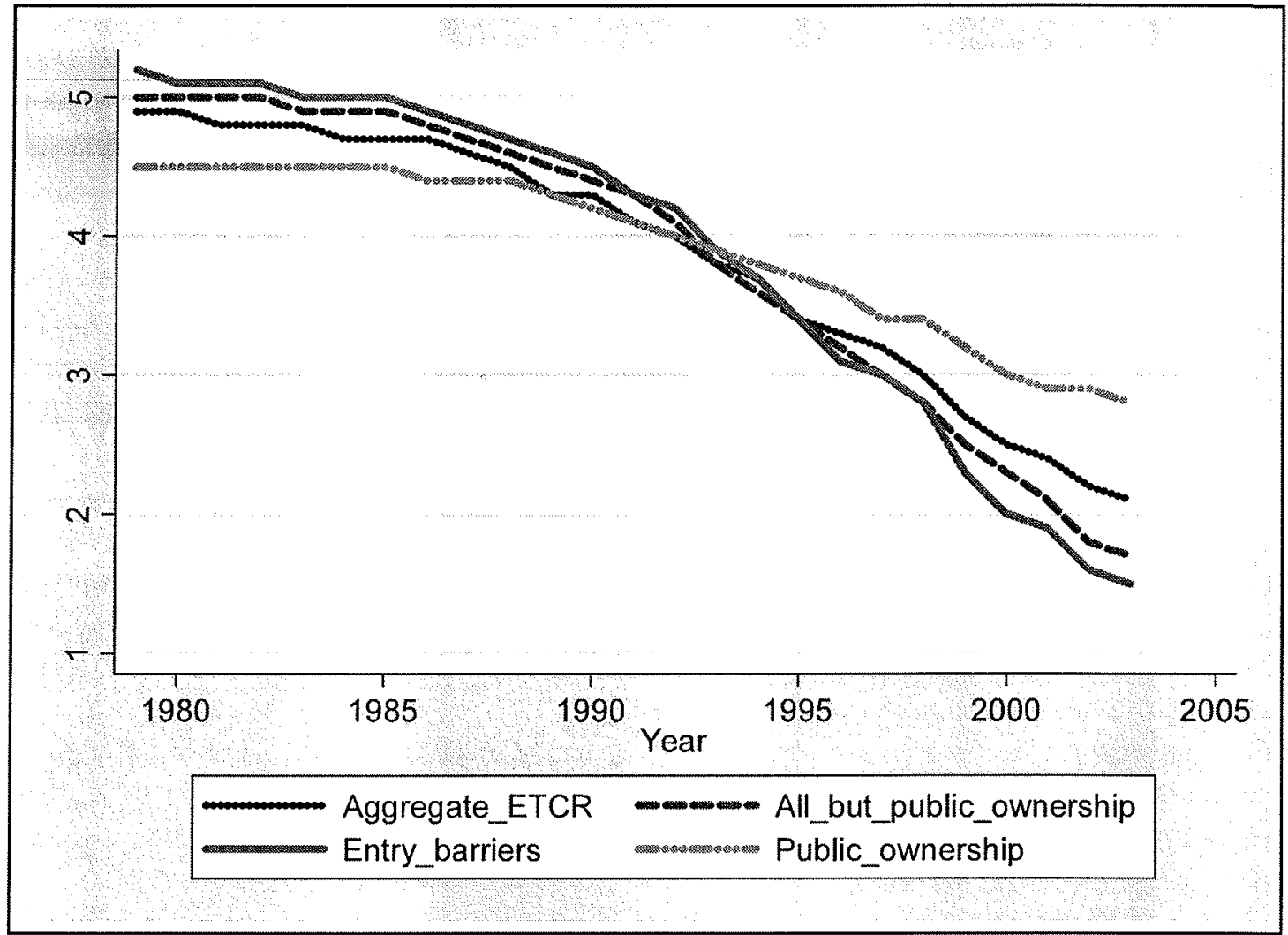

Fig. 1 Averages aggregated product market regulation indicators. 1979-2003. 21 OECD countries

Figures 1 and 2 illustrate that regulation in the analyzed sectors was restrictive in OECD countries in the end of the 1970s. Over the period from the beginning of the $1980 \mathrm{~s}$ to 2003 , changes have been made in most of the regulatory areas covered by the indicators, but were most spectacular in reducing entry barriers, and to a lesser extent, public ownership. In any event, the data show a clear-cut trend that needs to be addressed in the econometric model. Figure 2 illustrates that the United States was the first country to begin reforming product market regulation in 1979. From the mid 1980s, a number of other countries, such as the United Kingdom, Canada, New Zealand, Japan and the Nordic European countries, also started to reform. In contrast, product market deregulation did not begin in other European countries and Australia until the early 1990s. For this reason, I examine the period from 1979 (in levels) when product market regulation started in the United States. I will use these four indicators on "Aggregate ETCR", "All but public ownership", "Entry barriers" and "Public ownership" as dependent variables in the econometric model.

\subsection{The empirical model}

The estimated dynamic panel data model has the following structure:

$\Delta \ln$ 'Product Market Regulation Index' ${ }_{i j t}$

$$
\begin{aligned}
& =\alpha \text { 'Ideology' }{ }_{i t}+\sum_{k} \beta_{k} \Delta \ln X_{i k t}+\sum_{l} \beta_{l} Z_{i l t} \\
& \quad+\gamma \Delta \ln \text { 'Product Market Regulation Index' }{ }_{i j t-1}+\eta_{i}+\varepsilon_{t}+u_{i j t} \\
& \text { with } i=1, \ldots, 21 ; j=1, \ldots, 4 ; k=1,2 ; l=1,2 ; t=1, \ldots, 24
\end{aligned}
$$




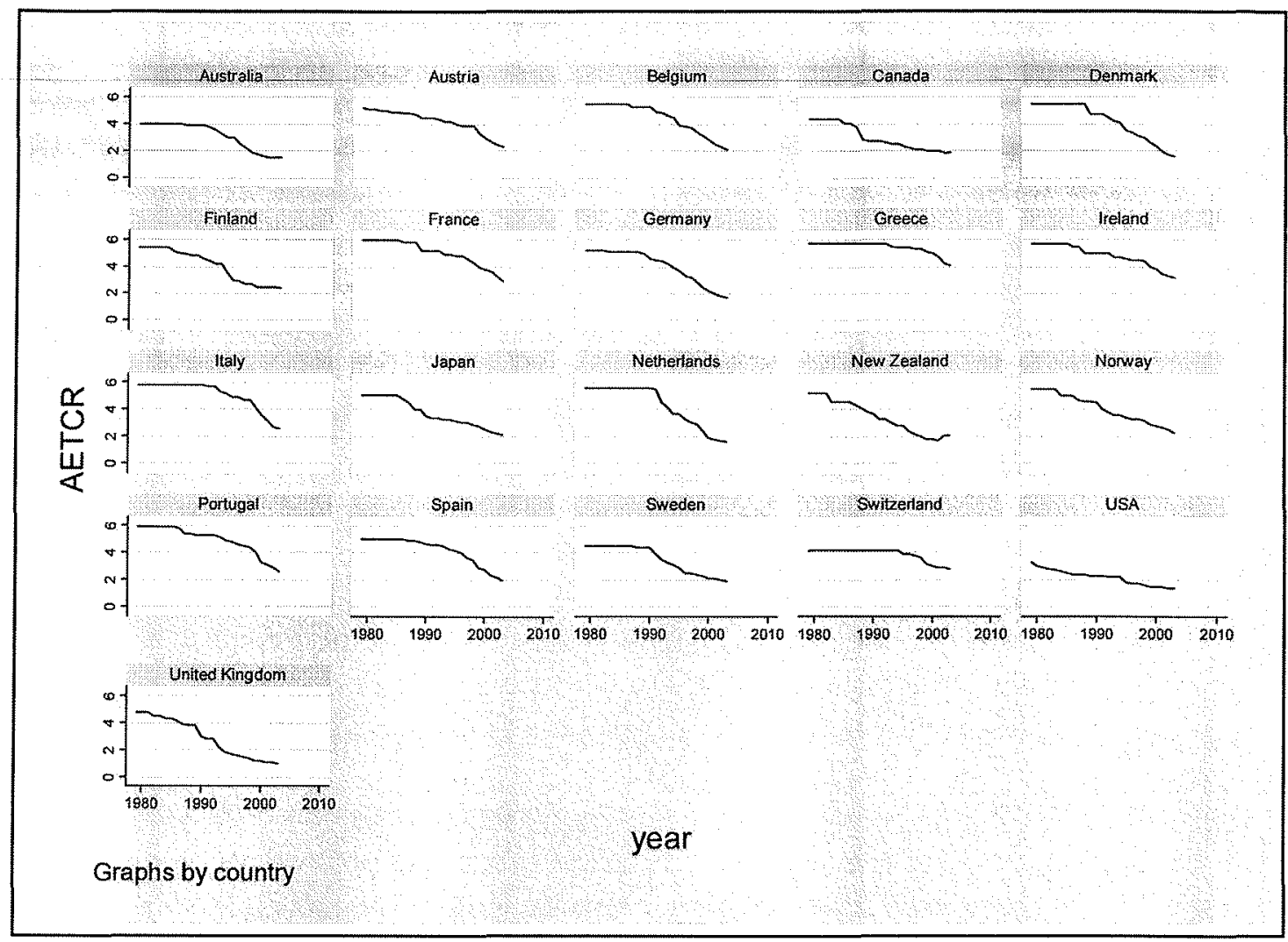

Fig. 2 Aggregated indicator measuring regulatory restrictions in energy, transport and communication (ETCR). 1979-2003. Single countries

where the dependent variable $\Delta \ln$ 'Product Market Regulation Index' ${ }_{i j t}$ denotes the growth rate of product market regulation index $j$. I distinguish between the four aggregated indicators of non-manufacturing regulation: "Aggregate ETCR", "All but public ownership", "Entry barriers" and "Public ownership". Panel data unit root tests show that these series are stationary in growth rates. 'Ideology' ${ }_{i t}$ describes the ideological orientation of the respective government. In the next paragraph I describe this variable and its coding in detail. $\sum_{k} \beta_{k} \Delta \ln X_{i k t}$ contains two exogenous economic control variables. I follow the related studies on the privatization processes in developed and developing countries to address the globalization process and therefore include the growth rate in the KOF index of globalization (KOF is an abbreviation for "Konjunkturforschungsstelle"-Swiss Economic Institute, see Dreher 2006 and Dreher et al. 2008a). Following the related studies on economic liberalization, I include the five-year average GDP per capita growth rate to address the product market deregulation as a potential reaction to economic crisis. In a similar vein, I follow Pitlik (2008) and Pitlik and Wirth (2003) and include the index on institutional constraints by Henisz (2000). This variable is captured by $\sum_{l} \beta_{l} Z_{i l t}$ in (1). $\sum_{l} \beta_{l} Z_{i l t}$ also describes the Herfindahl-Hirschman index of the legislature calculated by Bjørnskov (2008a) which is included to address different degrees of political competition. The appendix provides descriptive statistics of all variables included. The lagged dependent variable, $\Delta \ln$ 'Product Market Regulation Index' ${ }_{i j t-1}$, tackles the persistency of the deregulation indicators. Lastly, $\eta_{i}$ represents a fixed country effect, $\varepsilon_{t}$ is a fixed period effect and $u_{i j t}$ describes an error term. 
An important challenge in testing for the influence of government ideology in an OECD panel is the heterogeneity of the parties and parliamentary systems in the various nation states. The question is which governments should be labeled leftwing or rightwing especially when there are more than two parties in government with different ideological roots. I employ two alternative ideology indices that were used in recent empirical research: Potrafke (2009b) and Bjørnskov (2008a). The index proposed by Potrafke (2009b) is based on the index of governments' ideological positions by Budge et al. (1993) which has been updated by Woldendorp et al. $(1998,2000)$. This index places the cabinet on a left-right scale with values between 1 and 5 . It takes the value 1 if the share of governing rightwing parties in terms of seats in the cabinet and in parliament is larger than $2 / 3$, and 2 if it is between $1 / 3$ and $2 / 3$. The index is 3 if the share of centre parties is $50 \%$, or if the leftwing and rightwing parties form a coalition government that is not dominated by one side or the other. The index is symmetric and takes the values 4 and 5 if the leftwing parties dominate. Potrafke's (2009b) coding is consistent across time but does not attempt to capture differences between the party-families across countries. Years in which the government changed are labeled according to the government that was in office for the longer period, e.g., when a rightwing government followed a leftwing government in August, this year is labeled as leftwing.

Bjornskov's (2008a) index refers to the Henisz (2000) database on political outcomes since the 19th century, and the general approach to measuring political ideology follows along the lines of Bjørnskov (2005b, 2008b). However, as compared to the index employed in Bjørnskov (2005b, 2008b), the Bjørnskov (2008a) index "takes the social democrat party in a given country as an internationally comparable anchor around which other parties are placed on a five-point scale $(-1 ;-.5 ; 0 ; .5 ; 1)$ from left to right" (Bjørnskov 2008a: 5). The ideology scores of each government party are weighed with their relative share of all government party seats in parliament in order to consider differing degrees of influence on government policy. This procedure addresses the ideological position of the government and the parliament.

The Bjørnskov (2008a) index stresses the potential importance of the domestic political environment, in particular whether governments have a majority in parliament or not. It is important to note that Potrafke's (2009b) coding implies a positive influence of government ideology (leftwing) on product market regulation, whereas Bjørnskov's (2008a) coding implies a negative influence of government ideology (rightwing) on product market regulation. The correlation between the two government ideology indices is 0.70 . I enter the government ideology variables in levels. In fact, this implies that leftist and rightwing governments implement their preferred policies incrementally. ${ }^{8}$

I now turn to discussing my choice of the panel data estimation method. In the context of dynamic estimation, the common fixed-effect estimator is biased. The estimators taking into account the resulting bias can be broadly grouped into a class of instrumental estimators and a class of direct bias corrected estimators (see Behr 2003, for example, for a discussion). In accordance with large sample properties of the GMM methods, e.g., the estimator proposed by Arellano and Bond (1991) will be biased in my econometric model with $N=21$. For this reason, bias corrected estimators are more appropriate. Bruno (2005a, 2005b) presents

\footnotetext{
${ }^{8}$ This is a significant point because politicians implement their preferred policies step by step during the legislative periods. Therefore, for example, it would not be reasonable to regress the growth rates of the product market deregulation indicators on the growth rates of the government ideology variables.
} 
a bias corrected least squares dummy variable estimator for dynamic panel data models with small $N$ which I apply. ${ }^{9}$

\section{Results}

\subsection{Basic results}

Table 1 illustrates the regression results when the Potrafke index is used and reports the coefficients and $t$-statistics (in absolute terms) for every single equation. The two economic control variables, five-year average of the per capita income and the KOF index of globalization, are statistically insignificant. In contrast, the lagged dependent variable turns out to be highly statistically significant with a coefficient of about 0.15 across the specifications.

Table 1 Regression results. Dynamic bias corrected estimator. Dependent variable: growth rates of the product market regulation indicators. Potrafke government ideology index

\begin{tabular}{lllll}
\hline & $\begin{array}{l}\text { (1) } \\
\text { Aggregate } \\
\text { ETCR }\end{array}$ & $\begin{array}{l}\text { (2) } \\
\text { All but public } \\
\text { ownership }\end{array}$ & $\begin{array}{l}(3) \\
\text { Entry barriers }\end{array}$ & $\begin{array}{l}(4) \\
\text { Public } \\
\text { ownership }\end{array}$ \\
\hline Ideology (leftwing) & $0.0066^{* *}$ & 0.0048 & $0.0097^{*}$ & $0.0114^{* * *}$ \\
& {$[2.44]$} & {$[1.40]$} & {$[1.78]$} & {$[3.08]$} \\
$\Delta$ In KOF index of globalization & 0.1114 & 0.0981 & 0.2161 & -0.0621 \\
& {$[1.27]$} & {$[0.87]$} & {$[1.20]$} & {$[0.51]$} \\
$\Delta$ In Per capita income & 0.3175 & 0.4849 & 0.7316 & 0.1061 \\
(five-year average) & {$[1.29]$} & {$[1.53]$} & {$[1.45]$} & {$[0.31]$} \\
Institutional constraints (Henisz) & 0.0245 & 0.0292 & 0.0061 & 0.0172 \\
& {$[0.52]$} & {$[0.47]$} & {$[0.06]$} & {$[0.26]$} \\
Political competition (Herfindahl) & $-0.1182^{* * *}$ & $-0.0799^{*}$ & $-0.1967^{* * *}$ & $-0.1319^{* * *}$ \\
& {$[3.22]$} & {$[1.71]$} & {$[2.62]$} & {$[2.60]$} \\
Lagged dependent variable & $0.1181^{* *}$ & $0.2492^{* * *}$ & $0.1523^{* * *}$ & $0.1614^{* * *}$ \\
& {$[2.37]$} & {$[4.87]$} & {$[3.02]$} & {$[3.29]$} \\
Fixed country effects & Yes & Yes & Yes & Yes \\
Fixed period effects & Yes & Yes & Yes & Yes \\
Observations & & & & 483 \\
Number of countries & 483 & 483 & 483 & 21 \\
\hline
\end{tabular}

Notes: Absolute value of $t$ statistics in brackets; ${ }^{*}$ significant at $10 \% ;{ }^{* *}$ significant at $5 \% ;{ }^{* * *}$ significant at $1 \%$

\footnotetext{
${ }^{9}$ I choose the Blundell and Bond (1998) estimator as the initial estimator in which the instruments are collapsed as suggested by Roodman (2006). This procedure makes sure to avoid using invalid and too many instruments (see Roodman 2006 and 2009 for further details). Following Bloom et al. (2007) I undertake 50 repetitions of the procedure to bootstrap the estimated standard errors. Bootstrapping the standard errors is common practice applying this estimator. The reason is that Monte Carlo simulations demonstrated that the analytical variance estimator performs poorly for large coefficients of the lagged dependent variable (see Bruno $2005 \mathrm{~b}$ for further details). The results do not qualitatively change with more repetitions such as 100 , 200 or 500 or when the Arellano and Bond (1991) estimator is chosen as initial estimator.
} 
An $F$-test on the joint insignificance of the fixed period effects can strongly be rejected, which also indicates the persistence and time dependence of the dependent variables. The result of an overall trend of deregulation, however, does not depend on globalization which corresponds with related studies: Heinemann (2007) examines the influence of globalization on deregulation and also does not find statistically significant relationships between trade, capital mobility and product market deregulation. The lack of statistical significance of the five-year average of GDP per capita appears to be in line with the empirical findings by Pitlik (2008): pre-period GDP per capita growth is not related to economic liberalization. The coefficients of the institutional constraints indicator by Henisz (2000) have the expected positive sign (see Pitlik 2008 and Pitlik and Wirth 2003) but are not statistically significant. The Herfindahl-Hirschman index on legislative competition has the expected negative sign and is statistically significant indicating that product market deregulation occurred when political competition was at a low level.

The results in Table 1 show that government ideology has had a strong influence on product market deregulation: market-oriented and rightwing governments have been more active in deregulating product markets. The coefficient of the ideology variable in column (1) is statistically significant at the $5 \%$ level; it is significant at the $1 \%$ level in column (4) and at the $10 \%$ level in column (3) and slightly fails statistical significance in column (2). Their numerical meaning is that a corresponding increase of the ideology variable by one pointsay from 3 (leftist and rightwing parties in government) to 4 (leftwing government)-would increase the growth rate of the indicators by about $1 \%$. Against the background that the economic control variables are not statistically significant and the importance of the variables tackling the path dependency of the deregulation indicators the influence of the ideology is remarkable. Overall, the results of the sub indicators suggest that leftist governments, first of all, protected public ownership.

Table 2 provides the results when the Bjørnskov ideology index is used. As expected, the coefficients of this ideology index (rightwing) have a negative sign, and are statistically significant at the 5\% level in columns (1) and (3), at the $1 \%$ level in column (4) and at the $10 \%$ level in column (2). Thus, the result that market-oriented and rightwing governments promoted the deregulation of product markets is not sensitive to the chosen ideology measure.

\subsection{Robustness of the results}

I checked the robustness of the results in several ways. First, I will discuss an alternative econometric specification using somewhat different control variables and estimation procedure. The results in Tables 3 and 4 refer to regressions in which I have changed two features. First, the previous regressions included fixed period effects to address the continuation of the deregulation process over time. This persistence and path dependence could also be tackled by a linear time trend. Therefore, as a robustness check, I replace the fixed period effects by a linear time trend. To control for contemporaneous correlation across the countriesbecause deregulation appeared as an overall process in OECD countries-I apply panel corrected standard errors according to Beck and Katz (1996).

The regression results reported in Tables 3 and 4 illustrate that, as expected, the linear time trend is statistically strongly significant and has a negative sign. The HerfindahlHirschman index does not turn out to be statistically significant, whereas the five-year average of GDP per capita turns out to be statistically significant at the 5\% level in columns (2). The inferences with respect to the ideology variables on product market deregulation do not change at all. Their influence even somewhat increases and, therefore, stresses the important influence of government ideology on the product market deregulation process. 
Table 2 Regression results. Dynamic bias corrected estimator. Dependent variable: growth rates of the product market regulation indicators. Bjørnskov government ideology index

\begin{tabular}{lllll}
\hline & $(1)$ & $(2)$ & $(3)$ & $(4)$ \\
& $\begin{array}{l}\text { Aggregate } \\
\text { ETCR }\end{array}$ & $\begin{array}{l}\text { All but public } \\
\text { ownership }\end{array}$ & $\begin{array}{l}\text { Entry barriers } \\
\text { Public } \\
\text { ownership }\end{array}$ \\
\hline Ideology (rightwing) & $-0.0204^{* * *}$ & $-0.0183^{*}$ & $-0.0391^{* * *}$ & $-0.0374^{* * *}$ \\
& {$[2.76]$} & {$[1.93]$} & {$[2.59]$} & {$[3.63]$} \\
$\Delta$ ln KOF index of globalization & 0.1149 & 0.1008 & 0.2216 & -0.058 \\
& {$[1.30]$} & {$[0.89]$} & {$[1.23]$} & {$[0.48]$} \\
$\Delta$ In Per capita income & 0.3502 & 0.5101 & 0.7818 & 0.1635 \\
(five-year average) & {$[1.42]$} & {$[1.60]$} & {$[1.54]$} & {$[0.48]$} \\
Institutional constraints (Henisz) & 0.0188 & 0.0252 & -0.0009 & 0.0067 \\
& {$[0.40]$} & {$[0.41]$} & {$[0.01]$} & {$[0.10]$} \\
Political competition (Herfindahl) & $-0.1291^{* * *}$ & $-0.0881^{*}$ & $-0.2132^{* * *}$ & $-0.1510^{* * *}$ \\
& {$[3.54]$} & {$[1.90]$} & {$[2.87]$} & {$[3.02]$} \\
Lagged dependent variable & $0.1123^{* *}$ & $0.2440^{* * *}$ & $0.1424^{* * *}$ & $0.1526^{* * *}$ \\
& {$[2.29]$} & {$[4.84]$} & {$[2.89]$} & {$[3.17]$} \\
Fixed country effects & Yes & Yes & Yes & Yes \\
Fixed period effects & Yes & Yes & Yes & Yes \\
Observations & 483 & 483 & 483 & 483 \\
Number of countries & 21 & 21 & 21 & 21 \\
\hline
\end{tabular}

Notes: Absolute value of $t$ statistics in brackets; ${ }^{*}$ significant at $10 \% ;{ }^{* *}$ significant at $5 \% ;{ }^{* * *}$ significant at $1 \%$

I have included further economic and political control variables such as government size (total government expenditure as a share of GDP) and government debt (as a share of GDP). It is important to note that data on government debt are not available for all countries over the entire 1980-2003 sample period, so that the sample is reduced to 408 observations. I have also replaced the five-year average GDP per capita by a five-year average of unemployment. European Union membership could also play a significant part because the European Commission is often seen as a driving force of deregulation. For this reason, I have included a dummy variable that takes on the value one when the individual country was a member of the European Union and zero otherwise. ${ }^{10}$ All these variables, however, do not turn out to be statistically significant and do not change the inferences at all (Table 5). The results for the sub-indicators and when the Bjørnskov ideology index instead of the Potrafke ideology index is used are not shown but do not change the inferences.

Political decisions to deregulate product markets may well need time to be implemented, and the color of the government may change during this period. For this reason one may want to include lagged government ideology variables. When a single party has been in power for a fairly long time, however, lagged government ideology is less convincing because this particular party has been in office sufficiently long to implement its ideology-induced policy. In any event, to address potential time-lagged ideology effects on product market deregulation, I have replaced the government ideology variable in period $t$ by its lagged values in the

\footnotetext{
${ }^{10}$ EU members over the 1980-2003 period were: Belgium, Denmark, France, Germany, Ireland, Italy, the Netherlands and the UK. Greece joined in 1981. Spain and Portugal joined in 1986. Austria, Finland and Sweden joined in 1995.
} 
Table 3 Robustness tests. Panel corrected standard errors. Dependent variable: growth rates of the product market regulation indicators. Potrafke government ideology index

\begin{tabular}{lllll}
\hline & $(1)$ & $(2)$ & $(3)$ & $(4)$ \\
& $\begin{array}{l}\text { Aggregate } \\
\text { ETCR }\end{array}$ & $\begin{array}{l}\text { All but public } \\
\text { ownership }\end{array}$ & $\begin{array}{l}\text { Entry barriers } \\
\text { Public } \\
\text { ownership }\end{array}$ \\
\hline Ideology (leftwing) & $0.0080^{* * *}$ & 0.0050 & $0.0087^{*}$ & $0.0120^{* * *}$ \\
& {$[3.17]$} & {$[1.61]$} & {$[1.84]$} & {$[3.37]$} \\
$\Delta$ In KOF index of globalization & 0.0197 & 0.0876 & 0.1576 & -0.1066 \\
& {$[0.31]$} & {$[0.98]$} & {$[1.17]$} & {$[1.25]$} \\
$\Delta$ In Per capita income & 0.2569 & $0.4206^{* *}$ & 0.4256 & 0.2267 \\
(five-year average) & {$[1.64]$} & {$[2.25]$} & {$[1.54]$} & {$[0.84]$} \\
Institutional constraints (Henisz) & -0.0092 & -0.0126 & -0.0656 & -0.0237 \\
& {$[0.31]$} & {$[0.37]$} & {$[1.24]$} & {$[0.75]$} \\
Political competition (Herfindahl) & -0.0287 & -0.0071 & -0.0469 & -0.0256 \\
& {$[1.20]$} & {$[0.25]$} & {$[1.05]$} & {$[0.68]$} \\
Linear time trend & $-0.0033^{* * *}$ & $-0.0046^{* * *}$ & $-0.0062^{* * *}$ & $-0.0021^{* * * *}$ \\
& {$[10.09]$} & {$[11.02]$} & {$[9.54]$} & {$[4.46]$} \\
Constant & 0.0089 & 0.0223 & 0.0821 & 0.001 \\
& {$[0.30]$} & {$[0.62]$} & {$[1.47]$} & {$[0.03]$} \\
Fixed country effects & Yes & Yes & Yes & Yes \\
Fixed period effects & No & No & No & No \\
Observations & 504 & 504 & 504 & 504 \\
Number of countries & 21 & 21 & 21 & 21 \\
$R$-squared & 0.21 & 0.23 & 0.20 & 0.07 \\
\hline
\end{tabular}

Notes: Absolute value of $t$ statistics in brackets; ${ }^{*}$ significant at $10 \% ;{ }^{* *}$ significant at $5 \% ;{ }^{* * *}$ significant at $1 \%$

periods $t-1$ and $t-2$. The results show that influence of the lagged government ideology on product market deregulation decreases. Lagged government ideology (for both ideology indices) remains statistically significant in the static panel data models but does not turn out to be statistically significant at conventional levels in the dynamic panel data models. An important reason for the weaker effects of lagged government ideology is that marketoriented governments frequently rushed deregulation when elected to office. Examples are the changes in government after the elections in Sweden 1991 and in Spain 1996. ${ }^{11}$

A caveat applying to all panel data models concerns potential endogeneity of the explanatory variables. It is, however, not reasonable to believe that government ideology is influenced by product market deregulation in OECD countries. Good instrumental variables for government ideology are not available. Moreover, instrumenting ideology with the help

\footnotetext{
${ }^{11}$ The case study evidence on product market deregulation in Sweden shows that the Social Democrats started product market deregulation, but the market-oriented government in 1991-1994 indeed rushed deregulation. Most of the reforms undertaken by the market-oriented government were not reversed by Social Democratic governments from 1994 onwards. However, the Social Democrats delayed, for example, the deregulation of the electricity market for a year after winning the 1994 election (Bergh and Erlingsson 2009: $77 \mathrm{ff}$.). In Spain, the rightwing government drastically liberalized the economy after winning the 1996 election. The focus was, however, on privatization and much less on deregulation (see Ortega et al. 2003 for encompassing case study evidence).
} 
Table 4 Robustness tests. Panel corrected standard errors. Dependent variable: growth rates of the product market regulation indicators. Bjørnskov government ideology index

\begin{tabular}{lllll}
\hline & $(1)$ & $(2)$ & $(3)$ & $(4)$ \\
& $\begin{array}{l}\text { Aggregate } \\
\text { ETCR }\end{array}$ & $\begin{array}{l}\text { All but public } \\
\text { ownership }\end{array}$ & $\begin{array}{l}\text { Entry barriers } \\
\text { Public } \\
\text { ownership }\end{array}$ \\
\hline Ideology (rightwing) & $-0.0224^{* * *}$ & $-0.0164^{* *}$ & $-0.0263^{* *}$ & $-0.0365^{* * *}$ \\
& {$[3.41]$} & {$[2.04]$} & {$[2.07]$} & {$[3.29]$} \\
$\Delta$ In KOF index of globalization & 0.0205 & 0.0883 & 0.1614 & -0.107 \\
& {$[0.32]$} & {$[0.99]$} & {$[1.20]$} & {$[1.27]$} \\
$\Delta$ In Per capita income & 0.1637 & $0.3410^{*}$ & 0.3094 & 0.1287 \\
(five-year average) & {$[1.06]$} & {$[1.85]$} & {$[1.14]$} & {$[0.52]$} \\
Institutional constraints (Henisz) & -0.0076 & -0.0126 & -0.0683 & -0.0275 \\
& {$[0.25]$} & {$[0.37]$} & {$[1.28]$} & {$[0.85]$} \\
Political competition (Herfindahl) & -0.0207 & -0.0027 & -0.0427 & -0.0248 \\
& {$[0.85]$} & {$[0.10]$} & {$[0.96]$} & {$[0.64]$} \\
Linear time trend & $-0.0033^{* * *}$ & $-0.0046^{* * *}$ & $-0.0061^{* * *}$ & $-0.0021^{* * *}$ \\
& {$[9.94]$} & {$[11.06]$} & {$[9.47]$} & {$[4.47]$} \\
Constant & 0.0352 & 0.0405 & $0.1159^{* *}$ & $0.0503^{*}$ \\
& {$[1.25]$} & {$[1.21]$} & {$[2.23]$} & {$[1.75]$} \\
Fixed country effects & Yes & Yes & Yes & Yes \\
Fixed period effects & No & No & No & No \\
Observations & 504 & 504 & 504 & 504 \\
Number of countries & 21 & 21 & 21 & 21 \\
$R$-squared & 0.21 & 0.23 & 0.20 & 0.08 \\
\hline
\end{tabular}

Notes: Absolute value of $t$ statistics in brackets; ${ }^{*}$ significant at $10 \% ;{ }^{* *}$ significant at $5 \% ;{ }^{* * *}$ significant at $1 \%$

of lagged government ideology would not be reasonable because ideology is highly persistent.

In addition, I have tested for the existence of arbitrary serial correlation applying the Wooldridge test (Wooldridge 2002: 176-177) in the panel data model. The test result shows the absence of unrestricted serial correlation for any of the (de)regulation indicators.

The reported effects could depend on idiosyncratic circumstances in the individual countries. I therefore have tested whether the results are sensitive to the inclusion/exclusion of particular countries. The influence of the ideology variable somewhat declines when Canada, New Zealand and Spain are excluded. When Denmark is excluded, however, the influence of the ideology variables somewhat increases. This latter finding is consistent with the results in Bjørnskov (2008a) and may be due to the fact that since 1980 all rightwing governments were minority governments in Denmark. In any event, the inclusion/exclusion of a single country does not change the inferences.

\section{Conclusions}

Government ideology has had a strong influence on the product market deregulation process in OECD countries in the 1980-2003 period. This result confirms conventional wisdom and case studies because conservative governments such as the ones led by Margret 
Table 5 Rebustness tests. Dynamic bias corrected estimator. Dependent variable: growth rate of the overall product market regulation indicator. Further economic and political control variables. Potrafke government ideology index

\begin{tabular}{|c|c|c|c|c|}
\hline & $\begin{array}{l}\text { (1) } \\
\text { Aggregate } \\
\text { ETCR }\end{array}$ & $\begin{array}{l}(2) \\
\text { Aggregate } \\
\text { ETCR }\end{array}$ & $\begin{array}{l}(3) \\
\text { Aggregate } \\
\text { ETCR }\end{array}$ & $\begin{array}{l}\text { (4) } \\
\text { Aggregate } \\
\text { ETCR }\end{array}$ \\
\hline Ideology (leftwing) & $\begin{array}{l}0.0066^{* *} \\
{[2.45]}\end{array}$ & $\begin{array}{l}0.0082^{* * *} \\
{[3.26]}\end{array}$ & $\begin{array}{l}0.0066^{* *} \\
{[2.44]}\end{array}$ & $\begin{array}{l}0.0066^{* *} \\
{[2.43]}\end{array}$ \\
\hline$\Delta \ln \mathrm{KOF}$ index of globalization & $\begin{array}{l}0.1133 \\
{[1.29]}\end{array}$ & $\begin{array}{l}0.1091 \\
{[0.75]}\end{array}$ & $\begin{array}{l}0.1119 \\
{[1.25]}\end{array}$ & $\begin{array}{l}0.1119 \\
{[1.27]}\end{array}$ \\
\hline $\begin{array}{l}\triangle \ln \text { Per capita income } \\
\text { (five-year average) }\end{array}$ & $\begin{array}{l}0.3069 \\
{[1.27]}\end{array}$ & $\begin{array}{l}0.3387 \\
{[1.20]}\end{array}$ & & $\begin{array}{l}0.3052 \\
{[1.22]}\end{array}$ \\
\hline Institutional constraints (Henisz) & $\begin{array}{l}0.0231 \\
{[0.49]}\end{array}$ & $\begin{array}{l}0.0055 \\
{[0.09]}\end{array}$ & $\begin{array}{l}0.0226 \\
{[0.47]}\end{array}$ & $\begin{array}{l}0.0251 \\
{[0.53]}\end{array}$ \\
\hline Political competition (Herfindahl) & $\begin{array}{l}-0.1191^{* * *} \\
{[3.23]}\end{array}$ & $\begin{array}{l}-0.1364^{* * *} \\
{[2.70]}\end{array}$ & $\begin{array}{l}-0.1192^{* * *} \\
{[3.23]}\end{array}$ & $\begin{array}{l}-0.1182^{* * *} \\
{[3.21]}\end{array}$ \\
\hline Lagged dependent variable & $\begin{array}{l}0.1175^{* *} \\
{[2.34]}\end{array}$ & $\begin{array}{l}0.1292^{* *} \\
{[2.41]}\end{array}$ & $\begin{array}{l}0.1219^{* *} \\
{[2.41]}\end{array}$ & $\begin{array}{l}0.1176^{* *} \\
{[2.36]}\end{array}$ \\
\hline Government sector size & $\begin{array}{l}-0.0378 \\
{[0.43]}\end{array}$ & & & \\
\hline Central government debt & & $\begin{array}{l}-0.024 \\
{[0.68]}\end{array}$ & & \\
\hline $\begin{array}{l}\Delta \ln \text { Unemployment rate } \\
\text { (five-year average) }\end{array}$ & & & $\begin{array}{l}-0.018 \\
{[0.66]}\end{array}$ & \\
\hline EU membership & & & & $\begin{array}{l}0.0044 \\
{[0.42]}\end{array}$ \\
\hline Fixed country effects & Yes & Yes & Yes & Yes \\
\hline Fixed period effects & Yes & Yes & Yes & Yes \\
\hline Observations & 483 & 408 & 483 & 483 \\
\hline Number of countries & 21 & 21 & 21 & 21 \\
\hline
\end{tabular}

Notes: Absolute value of $t$ statistics in brackets; ${ }^{*}$ significant at $10 \% ;{ }^{* *}$ significant at $5 \% ;{ }^{* * *}$ significant at $1 \%$

Thatcher and Ronald Reagan are well known for their free market policies (Thatcherism and Reaganomics). 12 "Deregulation was, of course, the political project of the resurgent 'New Right' of the 1980s, most clearly visible in the Thatcher Government in Britain and the Reagan Administration in the United States" (Cerny 1991: 174). The econometric evidence supports the association of rightwing policies with the market-oriented school of thought including Hayek and Friedman, "both much admired by Margaret Thatcher" (Adams 1998: 84). Cukierman's and Tommasi's "When does it take a Nixon go to China"-Argument does not apply to product market reforms: Cukierman and Tommasi (1998) have argued that leftwing governments may well have more political credibility to convince the electorate of the need for reform and, thus, product market deregulation should have appeared under

\footnotetext{
${ }^{12}$ Deregulation of the US commercial airlines and of surface transportation actually began under Jimmy Carter, a Democrat, the stated purpose of which was to "fight" inflation.
} 
leftwing governments. It is true that product market reforms in countries such as Australia, New Zealand, Sweden and the United States began under leftwing governments, but the succeeding market-oriented governments did not simply let the initiated reforms pass but rather rushed the reform process.

Against the background that parties have changed over time, these results are significant. In the $1990 \mathrm{~s}$, the behavior of leftist governments changed as compared to the previous three decades. Leftist parties appear to have moved to the right in their rhetoric and policies (Ross 2000; Blyth and Katz 2005). In the course of globalization, leftist governments are, for example, believed to have lost the ability to implement their preferred policies such as direct income redistribution. The available empirical evidence for the OECD countries, however, does not indicate that globalization has had a negative influence on the welfare state. If anything, globalization rather expanded the welfare state (see Dreher et al. 2008a, 2008b; Potrafke 2009a, 2009b; Schulze and Ursprung 1999, and Ursprung 2008 for surveys of the literature on the nexus between globalization and the welfare state). Party ideologies change over time, and they do so irrespective of globalization. The most visible changes are a decline in political polarization and electoral cohesion. The constituencies of the political parties became less polarized over time, and class-specific voting patterns began to disappear towards the end of the 1970s (see, e.g., Mair 2008: $218 \mathrm{ff}$.). The decline in electoral cohesion led the parties to propose fewer client-targeted policy alternatives. ${ }^{13}$

Why is it that in the course of declining party ideologies product market deregulation emerges as a central policy field for policy differences between leftist and rightwing governments? First, in contrast to fiscal and social policies, industrial policy does not cause direct budgetary consequences. This finding is in line with Potrafke $(2009 \mathrm{c})$, who shows that government ideology has influenced political alignment with the US in voting in the UN General Assembly. Investigating UN General Assembly voting behavior of 21 OECD countries over the 1984-2005 period, Potrafke's (2009c) results indicate that leftwing governments were less sympathetic to US positions. The ideology-induced effect was stronger when the US President was a Republican. The distinctly different alignments of leftist and rightwing governments with the US reflect deeper sources of ideological association than would be predicted if the issues were solely those of economic policy on a left-right spectrum. Second, politicians are also election-motivated, and, for this reason, conservative governments in OECD countries did not substantially reduce core welfare programs such as public health. Popular support for the welfare state was just too strong (see, for example, Boix 1998). Ideological differences between leftist and rightwing governments in industrial policies, however, could be employed at lower electoral costs. In conclusion, my results suggest that industrial policy may well play a significant part in future policy debates.

Acknowledgements I thank Andreas Bergh, Christian Bjørnskov, William Shughart, Heinrich Ursprung and two anonymous referees for helpful hints and suggestions. Viktor Brech has provided excellent research assistance.

\footnotetext{
${ }^{13}$ The current empirical studies do not take into account that parties have undergone these changes which can only be captured by a dynamic index of voter polarization. See, for example, Potrafke (2008).
} 


\section{Appendix: Data description and sources}

Table 6 Descriptive statistics

\begin{tabular}{|c|c|c|c|c|c|c|}
\hline Variable & Observations & Mean & Std. Dev. & Min & Max & Source \\
\hline Aggregate ETCR & 525 & 4.03 & 1.30 & 1 & 6 & $\begin{array}{l}\text { Conway and } \\
\text { Nicoletti }(2006)\end{array}$ \\
\hline $\begin{array}{l}\text { All but public } \\
\text { ownership }\end{array}$ & 525 & 4.06 & 1.41 & 1 & 6 & $\begin{array}{l}\text { Conway and } \\
\text { Nicoletti (2006) }\end{array}$ \\
\hline Entry barriers & 525 & 4.06 & 1.57 & 0.3 & 6 & $\begin{array}{l}\text { Conway and } \\
\text { Nicoletti (2006) }\end{array}$ \\
\hline Public ownership & 525 & 4.04 & 1.37 & 0.7 & 6 & $\begin{array}{l}\text { Conway and } \\
\text { Nicoletti (2006) }\end{array}$ \\
\hline Ideology (leftwing) & 525 & 2.90 & 0.90 & 1 & 4 & $\begin{array}{l}\text { Potrafke } \\
(2009 \mathrm{~b})\end{array}$ \\
\hline Ideology (rightwing) & 525 & 0.29 & 0.38 & -0.57 & 1 & $\begin{array}{l}\text { Bjørnskov } \\
(2008 \mathrm{a})\end{array}$ \\
\hline $\begin{array}{l}\text { KOF index of } \\
\text { globalization }\end{array}$ & 525 & 73.50 & 12.32 & 43.26 & 93.65 & $\begin{array}{l}\text { Dreher (2006) } \\
\text { and Dreher } \\
\text { et al. }(2008 b)\end{array}$ \\
\hline $\begin{array}{l}\text { five-year average } \\
\text { GDP per capita } \\
\text { (real, local } \\
\text { currencies) }\end{array}$ & 525 & 204510.1 & 704277.4 & 6166.26 & 3953012 & $\begin{array}{l}\text { Worldbank } \\
(2009)\end{array}$ \\
\hline $\begin{array}{l}\text { Institutional } \\
\text { constraints }\end{array}$ & 525 & 0.77 & 0.09 & 0.33 & 0.89 & Henisz (2000) \\
\hline $\begin{array}{l}\text { Political competition } \\
\text { (Herfindahl- } \\
\text { Hirschman } \\
\text { index) }\end{array}$ & 525 & 0.33 & 0.11 & 0.11 & 0.63 & $\begin{array}{l}\text { Bjørnskov } \\
(2008 \mathrm{a})\end{array}$ \\
\hline $\begin{array}{l}\text { Size of Government } \\
\text { (total expenditures } \\
\text { as a share of GDP) }\end{array}$ & 525 & 17.62 & 4.19 & 7.36 & 27.95 & $\begin{array}{l}\text { Penn World } \\
\text { Tables } 6.2\end{array}$ \\
\hline $\begin{array}{l}\text { Central Government } \\
\text { Debt (as a share of } \\
\text { GDP) }\end{array}$ & 429 & 51.61 & 27.77 & 6.21 & 140.91 & OECD (2009) \\
\hline $\begin{array}{l}\text { five-year average } \\
\text { Unemployment rate } \\
\text { (\% of labor force) }\end{array}$ & 525 & 7.32 & 3.93 & 0.28 & 22.26 & OECD (2007) \\
\hline EU membership & 525 & 0.54 & 0.50 & 0 & 1 & Own collection \\
\hline
\end{tabular}


Table 7 Variable description

\begin{tabular}{|c|c|c|}
\hline Variable & Description & Source \\
\hline Entry barriers & 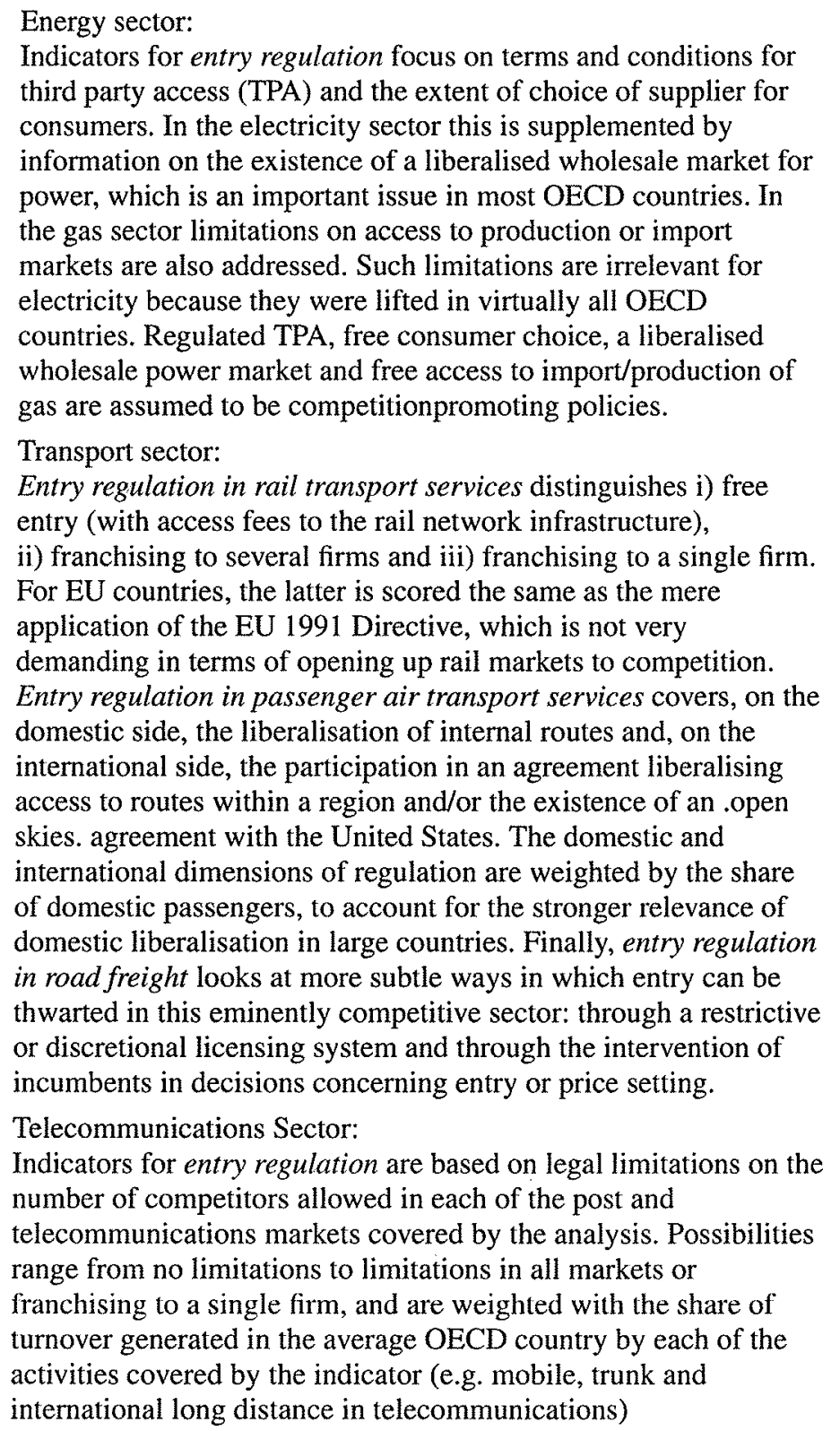 & $\begin{array}{l}\text { Conway and } \\
\text { Nicoletti }(2006)\end{array}$ \\
\hline OHC OWHETSIIIP & $\begin{array}{l}\text { Energy sector: } \\
\text { Indicators for public ownership record the prevailing ownership } \\
\text { structure in the various segments of the electricity and gas sectors, } \\
\text { ranging from fully private to fully public. The scoring allows for } \\
\text { mixed ownership arrangements in which the natural monopoly } \\
\text { segments remain under public hand. } \\
\text { Transport sector: } \\
\text { As mentioned above, public ownership in road freight is not } \\
\text { covered, because no OECD government has any relevant stake in } \\
\text { this industry. Public ownership in rail and air transport is, in both } \\
\text { cases, covered by reporting the percentage shares owned by the } \\
\text { government in the largest company (separately for infrastructure, } \\
\text { passenger transport and freight transport in rail). }\end{array}$ & $\begin{array}{l}\text { Conway and } \\
\text { Nicoletti }(2006)\end{array}$ \\
\hline
\end{tabular}


Table 7 (Continued)

\begin{tabular}{|c|c|c|}
\hline Variable & Description & Source \\
\hline . & $\begin{array}{l}\text { Communications sector: } \\
\text { Indicators for public ownership record, in ways that are } \\
\text { appropriate to each industry, the extent of government control in } \\
\text { the various post and telecommunications services, using the same } \\
\text { structure of weights as for the entry indicator. }\end{array}$ & \\
\hline \multirow[t]{3}{*}{$\begin{array}{l}\text { Rest categories } \\
\text { (complementing } \\
\text { The aggregate } \\
\text { ETCR) }\end{array}$} & $\begin{array}{l}\text { Energy sector: } \\
\text { Indicators for vertical integration focus on whether competitive } \\
\text { activities such as generation of electricity, production of gas, and } \\
\text { supply of both to the final consumer are separated from natural } \\
\text { monopoly activities such as the national grid and/or local } \\
\text { distribution. The degree of separation ranges from full integration } \\
\text { to mere legal/accounting separation to separation into different } \\
\text { companies owned by different shareholders. The assumption here, } \\
\text { reflecting industrial organisation theory, is that the scope for } \\
\text { anticompetitive behaviour is largest when an electricity or gas } \\
\text { company simultaneously controls the network and operates in } \\
\text { upstream or downstream competitive markets (see OECD 2007). } \\
\text { An indicator of market structure in the gas industry records the } \\
\text { market shares of the largest companies in the various segments of } \\
\text { the industry to (somewhat crudely) capture the extent to which the } \\
\text { regulatory framework succeeds in moderating the market power of } \\
\text { incumbents. }\end{array}$ & $\begin{array}{l}\text { Conway and } \\
\text { Nicoletti }(2006)\end{array}$ \\
\hline & $\begin{array}{l}\text { Transport sector: } \\
\text { Vertical integration is an issue only in the rail transport industry, } \\
\text { for which a low-level indicator similar to the indicators for the } \\
\text { energy industries is constructed. Here, the assumption is that the } \\
\text { possible economies of scope from integrating infrastructure and } \\
\text { services do not outweigh the advantages of unbundling in terms of } \\
\text { easier regulatory oversight and stronger downstream competition. } \\
\text { Market structure is reported only for rail transport to distinguish } \\
\text { franchising to several companies, each operating as a local } \\
\text { monopoly, from franchising to several firms competing with each } \\
\text { other in a given geographical area. }\end{array}$ & \\
\hline & $\begin{array}{l}\text { Communications sector: } \\
\text { Finally, a low-level indicator for market structure in } \\
\text { telecommunications is based on the market share of new entrants } \\
\text { in each of the telecommunications services covered by the } \\
\text { indicator to gauge the extent to which existing regulations actually } \\
\text { succeed in promoting competition. }\end{array}$ & \\
\hline $\begin{array}{l}\text { KOF index of } \\
\text { globalization }\end{array}$ & $\begin{array}{l}\text { The KOF Index of Globalization was introduced in } 2002 \text { (see } \\
\text { Dreher 2006). The overall index covers the economic, social and } \\
\text { political dimensions of globalization. It defines globalization to be } \\
\text { the process of creating networks of connections among actors at } \\
\text { multi-continental distances, mediated through a variety of flows } \\
\text { including people, information and ideas, capital and goods. } \\
\text { Globalization is conceptualized as a process that erodes national } \\
\text { boundaries, integrates national economies, cultures, technologies } \\
\text { and governance and produces complex relations of mutual } \\
\text { interdependence. }\end{array}$ & $\begin{array}{l}\text { Dreher (2006), } \\
\text { Dreher et al. } \\
(2008 \mathrm{a})\end{array}$ \\
\hline
\end{tabular}


Table 7 (Continued)

\begin{tabular}{|c|c|c|}
\hline Variable & Description & Source \\
\hline & $\begin{array}{l}\text { More specifically, the three dimensions of the KOF index are } \\
\text { defined as: } \\
\text { - economic globalization, characterized as long distance flows of } \\
\text { goods, capital and services as well as information and percep- } \\
\text { tions that accompany market exchanges; } \\
\text { - political globalization, characterized by a diffusion of govern- } \\
\text { ment policies; and } \\
\text { - social globalization, expressed as the spread of ideas, informa- } \\
\text { tion, images and people. }\end{array}$ & \\
\hline $\begin{array}{l}\text { Institutional } \\
\text { constraints }\end{array}$ & $\begin{array}{l}\text { This variable measures the degree of institutional constraints on } \\
\text { the executive regardless of the level of democracy. It is derived } \\
\text { from a simple spatial model of politics including five possible veto } \\
\text { points: the executive, one or two legislative chambers, the } \\
\text { judiciary and autonomous sub-central governments. Veto actors } \\
\text { are counted only if they act independently. In calculating the } \\
\text { index, Henisz takes into account the fragmentation of legislatures } \\
\text { and diverting policy preferences of veto actors. The index ranges } \\
\text { from } 0 \text { to a theoretical maximum of } 1 \text {. Higher index-values } \\
\text { indicate stronger constraints on the executive to change policies } \\
\text { autonomously (cited from Pitlik } 2008: 271 \text { ). }\end{array}$ & Henisz (2000) \\
\hline $\begin{array}{l}\text { Herfindahl- } \\
\text { Hirschman } \\
\text { Index }\end{array}$ & $\begin{array}{l}\text { This index captures the degree of formal political competition. It is } \\
\text { calculated as the sum of squares of the share of seats held by any } \\
\text { party in parliament. The index takes on values between } 0 \\
\text { (maximum of competition) and } 1 \text { (minimum of competition). }\end{array}$ & $\begin{array}{l}\text { Bjørnskov } \\
(2008 \mathrm{a})\end{array}$ \\
\hline
\end{tabular}

\section{References}

Adams, I. (1998). Ideology and politics in Britain today. Manchester/New York: Manchester University Press.

Alesina, A., Roubini, N., \& Cohen, G. D. (1997). Political cycles and the macroeconomy. Cambridge: The MIT Press.

Arellano, M., \& Bond, S. (1991). Some tests of specification for panel data: Monte Carlo evidence and an application to employment equations. Review of Economic Studies, 58(2), 277-297.

Arin, K. P., \& Ulubaşoğlu, M. A. (2009). Leviathan resists: the endogenous relationship between privatization and firm performance. Public Choice, 140(1-2), 185-204.

Bassanini, A., \& Duval, R. (2006). Employment patterns in OECD countries: reassessing the role of policies and institutions. OECD Social, Employment and Migration Working Papers No 35.

Beck, N., \& Katz, J. N. (1996). Nuisance vs. substance: specifying and estimating time-series cross section models. Political Analysis, 6(1), 1-36.

Behr, A. (2003). A comparison of dynamic panel data estimators: Monte Carlo evidence and an application to the investment function. Discussion paper 05/03, Economic Research Centre of the Deutsche Bundesbank.

Benoit, K., \& Laver, M. (2006). Party policy in modern democracies. New York: Routledge.

Berger, H., \& Danninger, S. (2007). The employment effects of labor and product market deregulation and their implications for structural reform. IMF Staff Papers, 54(3), 591-619.

Bergh, A., \& Erlingsson, G. Ó. (2009). Liberalization without retrenchment: understanding the consensus on Swedish welfare state reforms. Scandinavian Political Studies, 32(1), 71-93.

Bjørnskov, C. (2005a). Political ideology and economic freedom. Working Paper 05-8. University of Aarhus.

Bjørnskov, C. (2005b). Does political ideology affect economic growth?. Public Choice, 123(2), 133-146.

Bjørnskov, C. (2008a). Political ideology and the structure of national accounts in the Nordic Countries, 1950-2004. Paper presented at the annual meeting of the European Public Choice Society, Jena, 27-30 March 2008.

Bjørnskov, C. (2008b). The growth-inequality association: government ideology matters. Journal of Development Economics, 87(2), 300-308. 
Bjørnskov, C., \& Potrafke, N. (2009). Politics and privatization in Central and Eastern Europe: a panel data analysis. Paper presented at the annual meeting of the Public Choice Society, Las Vegas, 5-8 March 2009.

Bloom, D., Canning, D., Mansfield, R. K., \& Moore, M. (2007). Demographic change, social security systems, and savings. Journal of Monetary Economics, 54(1), 92-114.

Blundell, R. W., \& Bond, S. R. (1998). Initial conditions and moment restrictions in dynamic panel data models. Journal of Econometrics, 87(1), 115-143.

Blyth, M., \& Katz, R. (2005). From Catch-all politics to cartelisation: The political economy of the cartel party. West European Politics, 28(1), 33-60.

Boix, C. (1998). Political parties, growth and equality-conservative and social democratic economic strategies in the world economy. Cambridge: Cambridge University Press.

Bortolotti, B., \& Pinotti, P. (2008). Delayed privatization. Public Choice, 136(3-4), 331-351.

Bortolotti, B., Fantini, M., \& Siniscalco, D. (2001). Privatisation: politics, institutions, and financial markets. Emerging Markets Review, 2(2), 109-136.

Bortolotti, B., Fantini, M., \& Siniscalco, D. (2003). Privatisation around the world: evidence From panel data. Journal of Public Economics, 88(1-2), 305-332.

Bruno, G. S. F. (2005a). Approximating the bias of the LSDV estimator for dynamic unbalanced panel data models. Economics Letters, 87(3), 361-366.

Bruno, G. S. F. (2005b). Estimation and inference in dynamic unbalanced panel data models with a small number of individuals. Stata Journal, 5(4), 473-500.

Budge, I., Keman, H., \& Woldendorp, J. (1993). Political data 1945-1990. Party government In 20 democracies. European Journal of Political Research, 24(1), 1-119.

Cerny, P. G. (1991). The limits of deregulation: Transnational interpenetration and policy change. European Journal of Political Research, 19, 173-196.

Conway, P., \& Nicoletti, G. (2006). Product market regulation in the non-manufacturing sectors of OECD countries: measurement and highlights. OECD Economics Department Working Papers, No. 530, OECD Publishing. doi:10.1787/362886816127.

Cukierman, A., \& Tommasi, M. (1998). When does it take a Nixon go to China? American Economic Review, $88(1), 180-197$.

Dreher, A. (2006). Does globalization affect growth? Evidence from a new index of globalization. Applied Economics, 38(1), 1091-1110.

Dreher, A., Gaston, N., \& Martens, P. (2008a). Measuring globalization-understanding its causes and consequences. Berlin: Springer.

Dreher, A., Sturm, J.-E., \& Ursprung, H. W. (2008b). The impact of globalization on the composition of government expenditures: evidence from panel data. Public Choice, 134(3-4), 263-292.

Duso, T. (2007). On the politics of the regulatory reform: econometric evidence from OECD countries. WZB Working Paper FS IV 02-07.

Duval, R. (2008). Is there a role for macroeconomic policy in fostering structural reforms? Panel evidence from OECD countries over the past two decades. European Journal of Political Economy, 24(2), 491502.

Friedman, M. (1962). Capitalism and freedom. Chicago/London: The University of Chicago Press.

Heinemann, F. (2007). The drivers of deregulation in the era of globalization. In P. Bernholz \& R. Vaubel (Eds.), Political competition and economic regulation (pp. 245-266). New York: Routledge.

Henisz, W. (2000). The institutional environment for growth. Economics and Politics, I2(1), 1-31.

Imai, M. (2009). Ideologies, vested interest groups, and postal saving privatization in Japan. Public Choice, $138(1-2), 137-160$.

Kroszner, R. S., \& Strahan, P. E. (1998). What drives deregulation? Economics and politics of The relaxation of bank branching restrictions. NBER Working Paper 6637.

Kurrild-Klitgaard, P. (2005). The political economy of the dynamic nature of government intervention: an introduction to potentials and problems. Advances in Austrian Economics, 8, 3-20.

Mair, P. (2008). The challenge to party government. West European Politics, 31(1), 211-231.

Munger, M. C. (2008). Economic choice, political decision and the problem of limits. Public Choice, 137(34), 507-522.

OECD (2007). Health data. Paris.

OECD (2009). Main economic indicators. Paris.

Ortega, M. A., Sánchez, M. A., \& González, F. (2003). Privatization, deregulation and competition: evidence from Spain. Revista de Economia del Rosario, 6(1), 1-21.

Peacock, A. (1997). The political economy of economic freedom. Celtenham/Lyme: Edward Elgar Publishing.

Pitlik, H. (2007). A race to liberalization? Diffusion of economic policy reform among OECD-economies. Public Choice, 132(1), 159-178. 
Pitlik, H. (2008). The impact of growth performance and political regime type on economic policy liberalization. Kyklos, 6I(2), 258-278.

Pitlik, H., \& Wirth, S. (2003). Do crises promote the extent of economic liberalization? An empirical test. European Journal of Political Economy, 19(3), 565-581.

Potrafke, N. (2008). Parties change! Introducing a dynamic index on voter polarization. Paper presented at the annual meeting of the Public Choice Society, San Antonio 6-9 March 2008.

Potrafke, N. (2009a). Labor market deregulation and globalization: empirical evidence from OECD countries. Working Paper. University of Konstanz.

Potrafke, N. (2009b). Did globalization restrict partisan politics? An empirical evaluation of social expenditures in a panel of OECD countries. Public Choice, 140(1-2), 105-124.

Potrafke, N. (2009c). Does government ideology influence political alignment with the U.S.? An empirical analysis of voting in the UN General Assembly. Review of International Organizations (forthcoming).

Roodman, D. (2006). How to do xtabond2: an introduction to "Difference" and "System" GMM in Stata. Center for Global Development. Working Paper 103.

Roodman, D. (2009). A note on the theme of too many instruments. Oxford Bulletin of Economics and Statistics, 7l(1), 135-158.

Ross, F. (2000). "Beyond left and right": the new partisan politics of welfare. Governance: An international Journal of Policy and Administration, 13(2), 155-183.

Rowley, C., \& Rathbone, A. (2004). Political economy of antitrust. In N. Neuman \& J. Weigand (Eds.), The international handbook of competition (pp. 173-209). Cheltenham: Edward Elgar.

Sakamoto, T. (2008). Economic policy and performance in industrial democracies-party governments, central banks and the fiscal-monetary policy mix. London/New York: Routledge.

Schulze, G. G., \& Ursprung, H. W. (1999). Globalisation of the economy and the nation state. World Economy, 22(3), 295-352.

Tagkalakis, A. (2009). Fiscal adjustments: do labor and product market institutions matter? Public Choice, $139(3), 389-411$.

Ursprung, H. W. (2008). Globalisation and the welfare state. In S. N. Durlauf \& L. E. Blume (Eds.), The new Palgrave dictionary of economics (2nd edn.). Köln: Palgrave Macmillan.

Vaubel, R. (2008). The political economy of labor market regulation by the European Union. Review of International Organizations, 3(4), 435-465.

Woldendorp, J., Keman, H., \& Budge, I. (1998). Party government in 20 democracies: a update 1990-1995. European Journal of Political Research, 33(1), 125-164.

Woldendorp, J., Keman, H., \& Budge, I. (2000). Party government in 48 democracies 1945-1998: composition, duration, personnel. Dordrecht: Kluwer Academic Publishers.

Wooldridge, J. M. (2002). Econometric analysis of cross section and panel data. Cambridge: MIT Press.

Worldbank (2009). World development indicators online. Washington: Worldbank. 